\title{
NORTH KOSOVO AND THE SERBIA-KOSOVO NORMALIZATION DIALOGUE ${ }^{1}$
}

\section{Gustavo Oliveira Teles de Menezes San Tiago Dantas International Relations Program - São Paulo, Brazil}

\begin{abstract}
:
The article describes and discusses political and security trends in Serb-majority North Kosovo during the Serbia-Kosovo normalization process launched in 2011. Perspectives from the local Serb population in the face of the interests and policies of the governments of Serbia, Kosovo and the Western great powers that promote normalization are highlighted, showing that critical views of normalization and associated trends are widespread in North Kosovo. In this connection, it is argued that dissatisfaction and insecurity with normalization and associated trends also became present in the region's political life, pointing to latent challenges to the legitimacy and sustainability of normalization.
\end{abstract}

Keywords: Serbia, Kosovo, North Kosovo, European Union, Stabilitocracy

\section{Coresponding author:}

Gustavo Oliveira Teles de Menezes is a doctoral student at the San Tiago Dantas International Relations Program (São Paulo State University - Unesp, University of Campinas - Unicamp, Pontifical Catholic University of São Paulo - PUC/SP) and researcher at the National Institute of Science and Technology for Studies on the United States (INCT-INEU), both based in São Paulo, Brazil.

E-mail: gustavo.ot.menezes@unesp.br.

1 An earlier version of this paper was presented at the Annual International Conference of the Serbian Political Science Association (SPSA): “Conflict. Stability. Democracy?", 28-29 September 2019 in Belgrade. This study was financed in part by the Coordenação de Aperfeiçoamento de Pessoal de Nível Superior - Brasil (CAPES) - Finance Code ooı. 


\section{INTRODUCTION}

North Kosovo (hereafter the North), a 1,200 $\mathrm{km}^{2}$ - region adjacent to Central Serbia composed of the municipalities of Leposavić, the Northern part of Kosovska Mitrovica (henceforth North Mitrovica), Zubin Potok and Zvečan, has been known as a flashpoint in the Balkans since the end of the 1990 os Kosovo conflict. This is due to its overwhelmingly Serb population, estimated at around 70,0oo people (OSCE 2019), ${ }^{2}$ articulating with Belgrade to preserve institutions that were highly integrated with Serbia's political system, obstructing the administrative framework established under international auspices in Kosovo in 1999 and Kosovo's statehood after the latter's 2008 declaration of independence.

This situation meant a de facto partition in Kosovo opposed by Kosovo Albanian leaders and the Western great powers, who backed Priština's claim to sovereignty over the North. Solving this dispute became part of the European Union (EU)-mediated, United States of America (US)-supported Serbia-Kosovo normalization dialogue launched in 2011, whose progress became a condition for Serbia's desired EU accession. By making concessions that partly dismantled its remaining institutions in the North, Serbia advanced EU accession negotiations while keeping a significant degree of influence in the North and not recognizing Kosovo's independence. In its turn, Kosovo began expanding its authority in the North, a scenario seen by the Western powers as a stabilizing factor in the Balkans.

For its protagonists, thus, it can be said normalization has been a relative success, as Serbia, Kosovo and the Western powers attained some of their goals concerning the Serbia-Kosovo dispute and European integration. Similar assessments, however, hardly fit perspectives from most of the Northern Serb community, which was not meaningfully included in the negotiations. Although normalization's declared intents included guaranteeing security and the protection of rights for Kosovo Serbs, as well as better life conditions in the region (UN 2010; Serbia 2013c, 2019b), critical views of the dialogue and the general security and political environment in 'normalization-era' North are widespread among Northern Serbs, who overwhelmingly opposed living under Kosovo state authority.

In view of these conflicting perspectives, this paper describes and discusses political and security trends in normalization-era North. Attention is drawn to the perspectives and forms of political mobilization from the Northern Serb community in the face of the interests and policies of normalization's protagonists, i.e., the EU (and its leading states) and the governments of the US, Kosovo and particularly Serbia as the North's main

2 Besides the Serb majority, other communities (circa 10,0oo people), mainly Albanians and Bosniaks, also live in the North (OSCE 2019). 
supporter. In this connection, it is argued that local dissatisfaction and insecurity regarding normalization and associated trends became present in the region's political life, pointing to latent challenges to the legitimacy and sustainability of normalization.

By doing this, this paper aims to contribute to the literature on Kosovo Serb perspectives on peace-/state-building promoted by international and regional actors in Kosovo. ${ }^{3}$ It also hopes to contribute to debates on "stabilitocracy" in the Balkans, i.e., the contemporary pattern of relations according to which Western great powers seek geopolitical deference and the promise of stability from Balkan governments in exchange for tolerance and/or support for regimes with authoritarian features (Pavlović 2017; Bieber 2018).

The paper is structured as follows. The first section discusses the emergence and features of the Serbian Northern Kosovo system, as well as developments in the region, as a product both of the post-war context and the historical Serb-Albanian conflict in and over Kosovo. Then, normalization, its implications, perspectives and reactions from the North are analyzed in two following sections, one corresponding to the first, so-called technical phase of negotiations; and the second, corresponding to the political one and its aftermath. Finally, concluding remarks are provided in the last section. The article draws on the academic literature, policy papers, reports, official documents, press coverage, public opinion surveys and other material related to the paper's theme.

\section{THE NORTH: FROM THE EARLY POST-WAR PERIOD TO THE NORMALIZATION DIALOGUE}

The North Kosovo question and its developments during the normalization process are a direct product of the Kosovo status dispute that appeared in the aftermath of the 1990s conflict. At the same time, they also have deeper historical roots whose imprint is an important input for understanding the emergence of the Serbian Northern Kosovo system and developments in the region since 1999 .

Namely, the late nineteenth century witnessed the rise of the competing claims of the Serbian and Albanian national programs over the territory of present-day Kosovo. Since then, as Serbs and Albanians took turns as dominant groups in the region, political orders associated with these programs were often accompanied by forms of domination, discrimination and inequality (or perception thereof) experienced by both nations in relation to each other. Throughout history, polarization between Serbs and Albanians at times led to violent confrontations that further contributed 
to exacerbate tensions in their relations (Ristanović 2019, 8-14; Vladisavljević 2012, 34-35). In this connection, developments in Kosovo in the 1980s, when the region was an autonomous province within Serbia in socialist Yugoslavia, are of particular importance, as they inaugurated a new period of Serbian and Albanian national mobilization.

The 1981 massive protests by Kosovo Albanians seeking social equality and greater autonomy for Kosovo (or even an Albanian national unification) signaled, as Jović $(2009,183)$ put it, "the beginning of the state crisis of Yugoslavia". This was later followed by Kosovo Serb mobilization for closer links with Serbia and the overcoming of inter-ethnic inequalities. In 1989-1990, Serbia's leader Slobodan Milošević restricted Kosovo's autonomy and asserted control over the region. As Kosovo Albanians resisted this process, Belgrade responded with harsh repression and the curtailment of Albanians' participation in Kosovo's public sector. In reaction, the local Albanians created their own parallel institutions (Vladisavljević 2012, 27-28). Latent tensions in Kosovo escalated into a broader armed confrontation in the second half of the 1990s. The conflict between the forces of the Federal Republic of Yugoslavia (FRY)/Serbia and the Kosovo Albanian insurrection led by the Kosovo Liberation Army (KLA) eventually led to NATO's military intervention against the FRY/Serbia from March to June 1999.

As the conflict came to its end in June 1999, the United Nations Security Council (UNSC) adopted a peace framework based on its Resolution 1244 - which, despite its nominal commitment to FRY's/Serbia's territorial integrity and sovereignty, effectively meant the suspension of Belgrade's control over Kosovo. In its place, Resolution 1244 led to the establishment of the United Nations Interim Administration Mission in Kosovo (UNMIK), a civilian authority that later started partly transferring its competencies to local provisional self-governing bodies. The resolution also demanded the withdrawal from Kosovo of FRY's/Serbia's armed structures (which could, however, be deployed under minor, agreed-upon exceptions). Finally, the document authorized the deployment of the Kosovo Force (KFOR), an international NATO-led mission with a mandate for security in Kosovo (Headley 2008, 416; Ker-Lindsay 2009, 15-20; UN 1999).

The end of the conflict, however, did not immediately lead to a stable, peaceful environment. In the early post-war period, many Kosovo Serbs, fleeing persecution by Albanians throughout Kosovo, settled in the North, whilst part of the Albanian population persecuted by Serbs either fled or had its return to the North blocked. This process contributed to reinforce traditional Serbian demographic predominance in this part of Kosovo and turn it, for Serbs, into a secure area centered in North Mitrovica. The effective division between North Mitrovica and Albanian-majority Southern 
Kosovska Mitrovica, accompanied by periodic Serb-Albanian clashes, became one of the symbols of the North's separateness (ICG 2004, 44-52; 2005; Zupančič 2019, 579-580).

This demographic trend was accompanied by the maintenance of Serbian state institutions in Kosovo. Labeled internationally as "parallel structures" (OSCE 2003), they defied the institutional framework derived from Resolution 1244 - which Belgrade itself had accepted, and encouraged Kosovo Serbs to do so, in the early 2000 (Vladisavljević 2019, 176-178). ${ }^{4}$ Bolstered by a porous border with Central Serbia, Serbian state structures became especially strong in the North, where Serbs overwhelmingly favored links with Serbia against an Albanian-dominated independent Kosovo - on whose behalf the institutional framework derived from the international protectorate was often perceived to work (ICG 2005; 2012, 3; Zupančič 2019, 580).

This Serbian Northern Kosovo system was composed of several dimensions. Judicial, educational, healthcare, welfare and public administration organs functioned under Serbia's institutional system (ICG 2005; OSCE 2003). Serb-run security structures also functioned, obstructing the authority of the international protectorate's and Kosovo's security structures. Such was the case of the North Mitrovica-based Bridge Watchers (Čuvari mosta) group, ${ }^{5}$ the Civil Protection (Civilna zaštita, $\left.\mathrm{CZ}\right)^{6}$ and Serbia’s Ministry of Interior (Ministarstvo unutrašnjih poslova, MUP) staff. 7

4 Belgrade promoted Kosovo Serbs' participation in the 2001 parliamentary elections under Kosovo's Provisional Institutions of Self-Government (PISG). It should be noted, however, that the turnout in the North, where some local leaders opposed participation, was significantly lower than in other Serb-inhabited areas in Kosovo. Following the March 2004 antiSerb riots, Serb deputies left the PISG (ICG 2001, 13-19; 2009, 4-5). Additionally, the municipalities of Leposavić, Zubin Potok and Zvečan held local elections under international auspices in 2002, and had partially integrated with UNMIK in the early 2000 (ICG 2005, 5-6).

5 The name comes from the group's activities on crossings of the Ibar river, especially the main bridge linking North and South Mitrovica. Although partly financed by Serbia, the Bridge Watchers were mostly of local background. Active mainly in the early post-war years, they monitored and mobilized against international forces and Kosovo Albanians (especially preventing the latter's entry in the North) and performed police-like functions. Although often seen as reliable security providers by local Serbs, the Bridge Watchers monitored and reportedly harassed Serbs who cooperated (or were suspected thereof) with Albanians and international institutions. Allegedly, members of the group were also involved in crime (ICG 2002, 3-13; OSCE 2003, 12-14; 2007, 24-26; Zupančič 2019, 583).

6 The CZ was created by and subordinated to the Northern municipalities, while functioning under Serbia's funding through municipal budgets. Founded in 20o6, it formally dealt with emergency response tasks, but also performed security and, allegedly, intelligence functions. Many CZ members had military background, and some were believed to be former Bridge Watchers (Stakić and Bjeloš 2015, 10-13).

7 MUP staff performed security, police-like activities and the issuing of Serbian documents. It was believed MUP officers were also involved in the organization of violent episodes 
With contested state authority, rule of law was relatively weak, particularly in North Mitrovica. Crime (especially smuggling, often run in cooperation with Albanians) and political violence/intimidation, often directed against Serbs who cooperated with international or Kosovo institutions, became elements of the Northern society, generating insecurity and discontent among locals (Capussela 2016, 95-96; ICG 2011, 13-20; Insajder 2012).

The Serb-run North also had a party-political dimension. The Northern branch of Kosovo Serbs' Serbian National Council (Srpsko nacionalno veće, SNV) was the main local political organization. Through its leadership, it was linked to the nationalist-conservative Democratic Party of Serbia (Demokratska stranka Srbije, DSS), led by former FRY president (200o2003) and Serbian prime minister (2004-2008) Vojislav Koštunica. During the 200os, the DSS became the dominant party in the North. Despite some local discontent, the Northern Kosovo Serb leadership enjoyed popular legitimacy as administrators and community leaders (ICG 2009; Prelec and Rashiti 2015, 6-13). ${ }^{8}$

Local adherence to and dependence of this system among Northern Serbs can be attributed to several factors. First, there was the broad allegiance to the notion of a Serbian Kosovo. Second, employment and services provided by the Serbian institutions were perceived as good quality ones. Third, there was the question of inter-ethnic relations and Serb political (dis)enfranchisement in Kosovo. In the aftermath of the war, many Kosovo Serbs had experienced various forms of intimidation and violence, and their access and use of public services was often hindered. Amid this context, Kosovo Serbs often feared ethnic minorization and disrespected rights under Priština-centered institutions, even though the Constitutional Framework and the electoral system of the post-war international protectorate, in principle, guaranteed various rights for national communities

such as riots. Part of its officers worked covertly for the Kosovo Police (KP, known as Kosovo Police Service before Kosovo's declaration of independence). While the KP did function in the North with mostly Serb officers, it was influenced by the Northern Kosovo Serb leadership and largely ineffective and distrusted (being formally a Kosovo institution) (ICG 2005, 26-27; 2009, 5-6; 2011, 5, 16-19; OSCE 2003, 12-15; 2007, 24-27)

8 The DSS participated in ruling coalitions in Serbia for most of the first post-war decade after the fall of the Slobodan Milošević regime in October 200o. Although once favorable to EU accession, the party prioritized keeping Kosovo within Serbia over joining the bloc, as the EU was perceived as supportive of Kosovo's independence. This situation, coupled with the later recognition of Kosovo's independence by most EU member states, made the DSS shift to an ever more critical stance towards European integration (Vladisavljević 2019, 175-206). The SNV was founded by Kosovo Serbs in the late 1990s. Its Northern branch was led by Marko Jakšić, a former DSS local leader; and Milan Ivanović, head of North Mitrovica's regional hospital. The Northern SNV was involved in commercial and financial flows from Serbia, as well as local patronage networks. It was also believed to be behind political intimidation in the North (ICG 2005; 2009, 3-6). 
(Bieber 2015, 290; Clark 2014, 538-539; ICG 2009; OSCE 2003; Vladisavljević 2012, 30-35). It can be said, thus, that the Serbian Northern Kosovo system emerged as a product of both the post-war conditions in the region and of the historical Serb-Albanian conflict in and over Kosovo.

To some extent, elements of this Serb-run system functioned somewhat precariously, as it often had limited capabilities and competed or overlapped with other institutional frameworks. Nevertheless, it often enjoyed the highest degree of authority among Northern Serbs, leading to a de facto partition in Kosovo. This situation was partially tolerated by international organs, which, fearing instability, sought accommodation with the North. In the long run, however, a non-partitioned Kosovo was sought by Kosovo Albanian leaders and the Western powers. There were failed attempts by Kosovo Albanian leaders and international officials to extinguish the Serbian Northern Kosovo system already in the early 2000 (ICG 2002; 2005; 2011; OSCE 2003, 2007).

Challenges to the North also appeared during discussions on Kosovo's final status. A multi-ethnic, non-partitioned Kosovo was one of the principles agreed by the Contact Group (France, Germany, Italy, Russia, the United Kingdom and the US) for the Belgrade-Priština negotiations (Ker-Lindsay 2009). ${ }^{9}$ While Serbia, supported mainly by Russia, pushed for "more than autonomy, less than independence" for Kosovo in the 20062007 talks, Kosovo Albanians wanted independence - a solution favored by the US, the leading European countries and part of the UN/UNMIK apparatus (Ker-Lindsay 2009; Roriz 2015). For the Western powers, only independence for Kosovo could avoid destabilization by the dissatisfied Albanian majority (Capussela 2016, 87-92; Vladisavljević 2019, 178).

The talks resulted in Martti Ahtisaari's (UN's negotiation envoy) "supervised independence" proposal for Kosovo in 2007. The plan was supported by the Western powers, who promised backing Kosovo's independence with control of the North in exchange for protection of minorities. The so-called Ahtisaari Plan envisioned autonomy and enhanced rights/competencies in administrative, educational, healthcare, financial and police affairs, as well as funding and cooperation with Serbia, for Serb-majority municipalities (during the talks, Kosovo Serbs indeed sought control over education, healthcare, security and freedom of movement). Suggestion of Kosovo's independence, however, meant rejection by Serbia and Northern Serbs. Throughout 2007, large Kosovo Serb-organized rallies took place in North Mitrovica and Belgrade against the Ahtisaari plan and Kosovo's independence (Bilbija 2007; Capussela 2016, 99; Ker-Lindsay 2009, 41-42, 53-62, 98, 147-165). 
Facing Serbia's rejection and Russia's blocking of independence at the UNSC, the Kosovo Albanian leadership, acting in coordination with the Western powers, unilaterally declared Kosovo's independence in February 2008. The Ahtisaari Plan became the core of Kosovo's constitution (Ker-Lindsay 2009, 1-7; Nogueira 2015, 77-80, 214-224). As expected, this was rejected in Belgrade and the North. Despite ruling out military action to enforce its claim over Kosovo, Serbia started campaigning against the international recognition of Kosovo, strengthening ties with Russia for that end. These efforts included the September 2008 request at the United Nations General Assembly (UNGA) for an advisory opinion of the International Court of Justice (ICJ) about the legality of Kosovo's declaration of independence (Bieber 2015, 294-295; Economides and Ker-Lindsay 2015, 1032-1038). In the context of Kosovo's declaration of independence, Northern Serbs were involved in protests, attacks on border posts and clashes with international forces in the North (ICG 2008; 2009). The government of Serbia demanded Kosovo Serbs boycott Kosovo and EU institutions and organized municipal elections in the North in May 2008 under the Serbian system. Without forceful Western intervention, Priština was unable to assert its authority in the North (Capussela 2016, 95-96; ICG 2008, 2011). De facto partition, thus, remained.

The Western powers saw overcoming partition as a crucial step for stability in the Balkans. For American officials, the North's separateness was a dangerous precedent for other ethnic-territorial conflicts in the region (Traynor 2010). ${ }^{10}$ According to such thinking, a North integrated into Kosovo would lend credence to multi-ethnic state-building and consequently dismiss secessionisms not supported by the West (Capussela 2016, 107-111). In this connection, American and EU officials crafted the "Strategy for the North", a Priština-supported plan launched in 2009/2010 aiming to weaken the Serbian Northern Kosovo system and strengthen Kosovo's authority in the North through peaceful means. It was strongly rebuffed by Northern Serbs (ICG 2011, 9-11).

10 American fears of a partitioned Kosovo date back to the war and its immediate aftermath. During talks on the international peace framework for Kosovo in 1999, Russian representatives sought a Russia-commanded security sector in Northern Kosovo. The operational plan around the June 1999 Priština Dash also envisioned the possibility of the independent establishment of a Northern Russia-controlled sector. Taking into account the implications for NATO's role in Kosovo of Russia's (potential) autonomous behavior and pro-Serbian inclinations, US officials feared such Russian presence could lead to a de facto partition along the North. Eventually, however, it was agreed that Russian troops would participate in KFOR without their own sector, deployed mainly in Albanian-populated rural areas (rather than in the North) and as part of a single NATO command structure. In 2003, the Russian government, alleging lack of strategic interests in the Balkans and implicitly acknowledging its relatively weak influence over KFOR's operations, withdrew the Russian contingent (Gus'kova 2013, 251-257; Headley 2008, 393-416, 462). 
Challenges to the North were also sown in Belgrade. Following Serbia's May 2008 parliamentary election, the DSS was sidelined by the more pro-Western Democratic Party (Demokratska stranka, DS) led by president Boris Tadić. Under Western interference, the DS formed a coalition with the Socialist Party of Serbia (Socijalistička partija Srbije, SPS - formerly led by Slobodan Milošević), which embraced the European integration agenda on its path back to power (SPS 2010, 23-25; Trapara 2016, 213; Vladisavljević 2019, 202-206).

Although not all of its members recognize Kosovo's independence, the EU conditioned Serbia's integration with cooperative relations on/with Kosovo. The DS-led coalition, thus, despite not giving up the Serbian Northern Kosovo system and non-recognition of Kosovo's independence, started pursuing a more flexible Kosovo policy. This included acceptance of the EU's rule of law mission (EULEX) in the North and attempts to weaken the DSS-linked Northern Serb elite. Relations between the Northern Serb leadership and Belgrade started deteriorating (ICG 2011, 3-4; Vladisavljević 2019, 252-253).

More serious Serbian concessions came after the ICJ's July 2010 verdict, which did not consider Kosovo's declaration of independence a violation of international law. Under Brussels's pressure, the Serbian government proposed a joint resolution with the EU at the UNGA in September 2010 giving the EU a "status-neutral" mandate to mediate a Belgrade-Priština dialogue (Bieber 2015, 294-297; Vladisavljević 2019, 253). According to the document, the dialogue would be a "factor for peace, security and stability in the region", aimed to "achieve progress on the path to the European Union and improve the lives of the people" (UN 2010). Its approval signaled the beginning of the EU-mediated dialogue.

\section{THE NorTH AND THE TECHNICAL DIALOGUE (2011-2012)}

The EU-mediated, US-supported Serbia-Kosovo negotiations began with the so-called technical dialogue launched in March 2011. It dealt with seemingly neutral issues without explicitly addressing sensitive questions like Kosovo's statehood and its recognition by Serbia. Agreements were reached in 2011-2012 on freedom of movement, civil registry, custom stamps, cadastre, university diplomas and Kosovo's participation in regional cooperation initiatives (Đukanović 2013, 367-372; Emini and Stakić 2018, 4).

Despite its supposedly neutral nature, this phase did have serious implications for the North. In the context of trade talks, the government of Kosovo, aiming to enforce an embargo on Serbian goods (itself a retaliation for Serbia's refusal to accept goods with Kosovo customs stamps), force- 
fully attempted to establish control over border points in the North with special police units in July 2011. The attempt met violent resistance, as the operation was widely regarded by Northern Kosovo Serbs as an invasion challenging their community. This prompted confrontations with Kosovo and, for the following 18 months, EULEX and KFOR forces (both effectively aligned with Priština during the crisis) (Capussela 2016, 102-104; ICG 2012, 1-10; 2013, 1). ." Despite initial support for Northern Serb resistance, Serbia relented under Western pressure and withdrew its backing. In December 2011, a Belgrade-Priština deal was reached on Integrated Border-Boundary Management (IBM). Implemented by Serbia's next ruling coalition in 2012/2013, it effectively enhanced Priština's control over the Northern border and customs, triggering protests in the North (Đukanović 2013, 370-371; ICG 2013, 10-18; Mirović 2019, 54-58).

Amid this context, Northern Serbs, seeking protection, participated in a collective Kosovo Serb petition asking Russia for Russian citizenship in November 2011. Criticized by the Serbian government, the petition gathered about 20,000 signatures, but was eventually declined by the Russian government (which, on the other hand, sent humanitarian aid to Kosovo Serbs) (Politika 2011; Samedova 2012; Solov'ev 2011). In February 2012, a locally organized referendum on Kosovo institutions was held in the North. Rejected by official Belgrade, Priština and international actors, the voting had around 26,0oo participants, of which $99.74 \%$ rejected Kosovo institutions (Bieber 2015, 304; RTS 2012).

Pressures of the EU and its leading states, coupled with Belgrade's awareness of economic dependence towards the EU, were crucial for Serbia's policy shift towards normalization negotiations after the ICJ opinion. German pressure was particularly strong: prime minister Angela Merkel openly demanded the abolition of Serbian "parallel structures" during a visit to Belgrade in August 2011 (Economides and Ker-Lindsay 2015, 1034-1039; ICG 2012, 6-14). This process generated a deepening Belgrade-North rift.

In 2012, Serbia went through political changes with significant implications for normalization. The Serbian Progressive Party (Srpska napredna stranka, SNS) won parliamentary elections and formed a coalition with the SPS and other minor parties, a scenario that would repeat itself following parliamentary elections in 2014 and 2016. SNS leaders Tomislav Nikolić and Aleksandar Vučić also won presidential elections in 2012 and 2017 respectively.

11 Allegedly, vested interests of influential members of the Northern Kosovo Serb community in smuggling also significantly contributed to the escalation of the conflict (Insajder 2012). 
The SNS was born in 2008 when Nikolić, followed by Vučić, left the traditionally ultranationalist, popular Serbian Radical Party (Srpska radikalna stranka, SRS) to form the new party of more moderate views on the Kosovo question and European integration (Vladisavljević 2019, 204-205, 277-289). Despite its leaders' past in the SRS, as well as the new party's declared non-acceptance of Kosovo's independence and of the abolition of the Serbian Northern Kosovo system, the SNS, which also criticized past governments' Kosovo policies, advocated EU accession and negotiations on Kosovo - even admitting openness to possible "painful concessions" on both sides in order to achieve a solution for the Kosovo question (SNS 2011, 37-42).

SNS's EU-amenable stances, including on Kosovo, made the party-led governments gain Western support (Vladisavljević 2019, 285-287). With discredited domestic rivals, the SNS, through its popular leadership centered on the figure of Vučić; ${ }^{12}$ a large party and patronage network; cooptation and constraints towards opponents; and manipulation of state institutions and media, became Serbia's strongest political force, scoring expressive electoral victories and consolidating itself at the top of a regime with authoritarian features (Bieber 2020, 42-53; Pavlović 2020; Vladisavljević 2019, 277-313). The new Serbian leadership, increasingly centered on Vučić, started pushing an ambitious Kosovo agenda with serious implications for the North.

\section{The North AMID THE POLITICAL DiAlogUE AND BEYOND $(2012-\ldots)$}

The Serbia-Kosovo so-called political dialogue started in October 2012, while in January 2013 the Serbian government announced and adopted its guidelines for the negotiations. The documents stated that Serbia would not accept Kosovo's independence. Tellingly, on the other hand, it was acknowledged that normalization had given a degree of legitimacy to Kosovo's institutions and that the talks should deal with the "overcoming of institutional parallelisms". Serbia would implement past normalization agreements and seek an agreed, comprehensive solution for the Kosovo dispute, as well security and rights for Serbs inside Kosovo. Serbia would also seek autonomy for Serb-majority municipalities in Kosovo, which would have the right to cooperation with and financial support from

12 Although keeping ties with the party, Nikolić left the SNS after his 2012 presidential election victory, paving the way for Vučić's consolidation as SNS's sole leader (Bieber 2020, 50; Vladisavljević 2019, 286, 293-294). Before becoming president in 2017, Vučić was prime minister (2014-2017), first deputy prime minister (2012-2014) and minister of defense (2012-2013). 
Belgrade. Finally, the negotiations should contribute to Serbia's EU integration (Serbia 2013b, 2013c).

This approach was reflected in the landmark Brussels Agreement (officially the "First Agreement of Principles Governing the Normalization of Relations") of April 2013, which stipulated the integration of Serbia-affiliated police, security and judiciary personnel into Kosovo institutions according to ethnic proportionality. A Kosovo-wide Association/Community of Serb-majority Municipalities (Zajednica srpskih opština, ZSO) would be established under Kosovo's laws - but allowing funding from Serbia - with overview of economic, education, healthcare, social, urban and rural policies. Finally, municipalities would be formed and elections held in the North within Kosovo's institutional framework (Serbia 2013a; 2015). ${ }^{13}$ As a reward for the agreement, Serbia started EU accession talks in

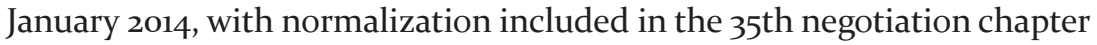
(Bieber 2015, 316).

The Brussels Agreement and its complements, thus, directly challenged the Serbian Northern Kosovo system. Since 2013, despite varying speed and remaining implementation disputes, key structures like police, security (MUP and CZ) and judiciary faced dismantling, with Serb officers being absorbed into equivalent Kosovo institutions - which, in turn, became more present in the North. ${ }^{14}$ Meanwhile, ZSO's implementation has barely progressed (BPRG 2017; Dragojlov 2020; Emini and Stakić 2018, 6; Serbia 2018; 2019b).

These concessions did not mean, however, that Serbia fully accepted Kosovo's statehood and the complete extinction of the Serbian Northern Kosovo system. Serbia has kept an enduring policy of non-recognition of Kosovo's independence during the normalization process. The Brussels Agreement, for example, was not ratified by the Serbian parliament, thus avoiding the implication of it having an international nature. A

13 A controversial complement of the 2013 negotiations that relates to recent security incidents in the North is NATO's role as security guarantor in the region, obtained at Serbia's insistence (Đukanović 2013, 373). Serbia has claimed that Kosovo special police units and the Kosovo Security Force (KSF, Kosovo's army in the making), can enter the North only with KFOR's and Northern Serb representatives' consent. KFOR and NATO, however, have claimed such agreement exists only regarding the KSF and do not mention the need for Northern Kosovo Serb representatives' authorization (B92 2019; Serbia 2018, 10-12; 2019b; Tuhina 2019). An official letter made public in 2020 shows that in 2013 Hashim Thaçi, then Kosovo's prime minister, assured NATO that the KSF would operate in the North only with prior concurrence from KFOR. The letter also states that KFOR "may engage with legitimate representatives of the local community in Northern Kosovo" as part of such concurrence process (EWB 2020b).

14 According to some sources, however, integrated police, security and judiciary personnel kept receiving pensions and compensations from the Serbian government, and were still seen as influenced by Belgrade even after the Brussels Agreement (Dragojlov 2020, 5-8). 
similar view was adopted by the Serbian Constitutional Court, which also affirmed that the Brussels Agreement did not determine Kosovo's final status (Bieber 2015, 307). Finally, Serbia has campaigned to block Kosovo's entry in some international organizations and for UN members to withdraw recognition of Kosovo's independence (Serbia 2019b). The Serbian government has at times shown a confrontational posture towards Priština, while pro-government tabloid media has often exhibited a chauvinistic rhetoric towards non-Serb nations in the regional neighborhood and a sensationalist discourse about supposedly imminent wars to be initiated by Kosovo Albanians (Đorđević 2019; Vladisavljević 2019, 304-310). Serbian national symbols remained filling the Northern landscape, visually signaling the region's enduring specificity.

Serbian institutions, on which Serbs still largely rely, kept functioning in Kosovo, including in the North - to a degree tolerated by Priština, but nevertheless criticized by Kosovo Albanian politicians (Andrić Rakić 2020; Loxha 2019; Prelec and Rashiti 2015, 30). Municipal administrative organs under the Serbian institutional system, whose officials sometimes simultaneously have posts in Kosovo institutions, still function (Kossev 2020; Loxha 2019). Serbian education, welfare and healthcare systems keep functioning, and the Serbian government has provided public spending and investments, donations and other kinds of support for Kosovo Serbs (sometimes in coordination with Priština and the EU) (Andrić Rakić 2020; HCHRS 2019; Kossev 2019c; Serbia 2018, 24-25; 2019b).

Finally, employment and income remained largely provided by Serbia. Estimates of Northern Kosovo Serbs relying on the Serbian budget range from $52.2 \%$ to as many as $80 \%$ (Jović and Nešović 2015, 22-23; Andrić Rakić 2017; Fazliu 2017; Prelec and Rashiti 2015). These factors, alongside the broad allegiance to the Serbian claim over Kosovo and potential problems regarding inter-ethnic relations and political (dis)enfranchisement under the Priština institutional system, contribute to the maintenance of the widespread Northern Serb sense of loyalty, belonging and dependence towards Serbia.

The Serbian government has attempted to offset normalization concessions through other channels of influence in Kosovo. This has been done mainly via Kosovo Serbs' participation in Kosovo's political system, taking advantage of the latter's ethnic representation and veto rights, as well as running Kosovo system municipalities with Serb majority. To this end, a new party-list controlled by the Serbian government, the Serbian List (Srpska lista, SL), was established in an attempt to unify Kosovo Serb politics under Belgrade's control. In the North, this meant the replacement of the old anti-integration leadership. This strategy was reinforced by the Kosovo Albanian elite's consent to engagement with the SL (since 
its inception, the SL has participated in coalitions and/or taken ministerial posts under every government in Kosovo), as well as with the reconfigured Northern Kosovo Serb elite linked to the party (Bieber 2015, 308-310; Butcher 2020; EWB 2020a; Fazliu 2017; Kossev 2019b; Milivojevic 2019; Mirović 2019, 119-128; Prelec and Rashiti 2015, 12-13; Zupančič 2019).

With impressive electoral results, ${ }^{15}$ the SL, labeled by the Serbian government as a "state project", came to power in Serb-majority municipalities and virtually monopolized Serb parliamentary representation in Kosovo (RFE 2019; Kossev 2019b; Serbia 2019a). Therefore, while certain policies of the Serbian government indeed meant a degree of legitimization of Priština's institutions, it can be argued, on the other hand, that the Kosovo Albanian leadership accepted a stake for Serbia in what Bieber $(2015,302)$ called a "de facto degree of shared sovereignty in parts of Kosovo".

The North Mitrovica-based SL affirms support both for the normalization process and Resolution 1244 (implying alignment with the resolution's reference to Serbia's territorial integrity) (SL N.d.). SL's rise can be partly attributed to genuine political loyalty towards Serbia among Northern Kosovo Serbs. However, this trajectory has also been marked by controversial circumstances that in some ways reproduce certain authoritarian features in Serbia's recent political history. There is the question, for example, of the use of state resources to foster compliance with the SL. Vučić himself, ahead of the 2019 Kosovo parliamentary election, publicly associated SL's electoral success with the maintenance of Serbian salaries in education and healthcare (RTS 2019), thus suggesting Belgrade's awareness of public sector dependence as a source of political influence over Kosovo Serbs.

In this connection, there are also reports of pressures on employees at Serbian institutions in the North (and throughout Kosovo) through means like collective voting and threats of dismissal (Jović, Andrić and Marinković 2017, 44; Marinković, Timotijević and Kostić 2019, 33-34; Trivić and Loxha 2019). Similar practices attributed to SNS activists are also reported to have occurred during elections in Serbia (Pavlović 2020, 25-26).

Belgrade's strategy of monopolizing Kosovo Serb politics was also accompanied by the SL's portrayal of opponents and alternative political forces as traitors of the nation and a threat to Serbian unity in Kosovo. This has often been done in a language that resembles that of Serbian govern-

15 In Kosovo's 2019 mayoral and parliamentary elections, for example, the SL got an average around $94 \%$ and $87 \%$ of votes, respectively, in the North (KCEC 2019a; 2019b). When it comes to Serbia's elections, SL's patrons in Belgrade scored similar degrees of electoral support. In the 2020 Serbian parliamentary election, the SNS-led electoral coalition received an average $85 \%$ of the votes in the North (Serbia 2020). 
ment and SNS officials, as well as the virulent rhetoric of pro-government media towards opponents and critics of Vučić. ${ }^{16}$ Taking into account the strong political and material attachment many Northern Kosovo Serbs have towards Serbia, the aforementioned factors constitute important tools of influence with constraining effects for democracy and political pluralism in the North.

Finally, there are reports and accusations of pressure, intimidation and even physical attacks against citizens, politicians and political groupings not aligned or critical of the SL, the Serbian government and the shadowy informal power "structures" believed to be linked to the Serbian government and to actually run politics and crime in the North (Emini and Stakić 2018, 6; Milivojevic 2019; Zupančič 2019, 581-587). Such reports also indicate that intimidation and political violence, as well as rule of law weakness, persist in the North, but not facing, as Zupančič (2019) noted, a strong rebuttal by the EU.

How do Northern Kosovo Serbs perceive these developments? Despite being among the ones most affected by normalization, Kosovo Serbs, including those from the North, were not meaningfully included in the process, a fact that shows an authoritarian facet of normalization. This happened despite the Serbian government stating that Kosovo Serbs would be heard during the negotiations (Jović and Nešović 2015, 11-12; Serbia 2013c). Additionally, there was ambiguity and lack of transparency, tricks the EU hoped would advance negotiations. Among Kosovo Serbs, this created sentiments of confusion, exclusion and the perception of being a mere bargaining chip in EU integration processes (Bieber 2015, 308-319; BPRG 2017, 24-26).

Public opinion surveys indicate that sentiments of this kind are widespread in the North. A 2016 poll, for example, found that around $70 \%$ of Northern Kosovo Serbs did not understand fully the ZSO agreement or see a citizens' role in its implementation (BPRG 2017, 39-40). Usually, few people expected that the ZSO would improve Serbs' position in Kosovo. Since 2015, support for the Brussels Agreement has on average reached about 15\%. While a resigned majority in 2015 supported Serbs' participation in Kosovo institutions, such support became minoritarian, averaging about $24 \%$ in 2016-2018. Usually fewer than $10 \%$ of citizens believed the Brussels Agreement unambiguously improved Kosovo Serbs' rights and freedoms (Jović and Nešović 2015, 13-15, 35; Jović, Andrić and Ostojić 2016,

16 See, for example, SL's communiqué in the aftermath of the 2019 Kosovo parliamentary election (SL 2019). For broader analyses of the rhetoric of representatives of the Serbian government, the SNS and pro-government media, as well as their relations, see Bieber (2020, 93, 126-128), Pavlović (2020, 26-29) and Vladisavljević (2019, 296-310). 
14-22, 25, 31; Jović, Andrić and Marinković 2017, 4, 27-35, 39-40, 47; Jović, Waugh and Marinković 2018, 22-32, 40).

Finally, in 2019, 66\% of Northern Kosovo Serbs, indicating a belief that (whole) Kosovo should be Serbian, opposed a "delineation" (razgraničenje) between Serbia and Kosovo - an idea commonly understood as containing an official territorial partition in the region with the North recognized as Serbia's territory. Serbian and some EU, US and Kosovo Albanian officials have recently indicated openness to this idea as a basis for a final normalization agreement (Marinković, Timotijević and Kostić 2019, 53-56; Kolesnikov 2018; Surk 2019; Xharra, 2020).

Satisfaction with and trust in Kosovo's and international institutions remained generally lower than in the Serbian government and Serb-run institutions, despite low trust rates in Kosovo Serb politicians and the existence of perceptions of the normalization-era, Belgrade-controlled Northern Serb leadership as illegitimate. The EU - often seen as biased, pro-Albanian - and the US are lowly rated as actors Kosovo Serbs can rely on in the pursuit of their interests. Both have sharply lower trust rates than Russia. The general political, security and economic environment in Kosovo has been rated overwhelmingly negatively, ${ }^{17}$ with acute perception of authoritarianism, criminality and weak rule of law. Since 2016, growing percentages of Northern Kosovo Serbs (as many as $78 \%$ in 2018) have claimed not to feel free to publicly express their political positions. Crime has constantly been cited among the top security risks/problems, sometimes ahead of ethnic-related and military issues (BPRG 2017, 35-36; CBS 2018; Jović and Nešović 2015, 28-30; Jović, Andrić and Ostojić 2016, 16-19, 28-34; Jović, Andrić and Marinković 2017; 25-31, 43-46, 51; Jović, Waugh and Marinković 2018, 20-25, 35, 39-40, 45; Marinković, Timotijević and Kostić 2019, 44).

These critical assessments are present in Northern Kosovo Serb political life and, like at the time of the technical dialogue, generated political mobilization. In 2013, for example, the Brussels Agreement was rejected by some Northern Serb representatives. Protests against normalization agreements led by the old Northern Kosovo Serb leadership were held in Belgrade and the North, attracting thousands of citizens (Al Jazeera 2013; Mirović 2019, 99-105). Despite Belgrade's pressure for participation and the SL's eventual (and controversial) victory, the first local elections under

17 Between around 2/3 to 4/5 of interviewed Northern Kosovo Serbs usually assessed the situation as bad or very bad in these three realms, with little expectation of life improvements for Kosovo Serbs in the near future. Polls also registered growing willingness to emigrate, especially among the youth (Jović and Nešović 2015, 12, 20, 27, 38; Jović, Andrić and Ostojić 2016, 9-11, 31-32; Jović, Andrić and Marinković 2017, 12-15, 49; Jović, Waugh and Marinković 2018, 10-12, 41-42; Marinković, Timotijević and Kostić 2019, 12-15) 
Kosovo's system in 2013-2014 were largely rejected by the old Northern Serb leadership and the Serb community, often resulting in low turnouts (Bieber 2015, 309-310; Đukanović 2013, 378-379; Mirović 2019, 119-124; Zupančič 2019, 590). Criticism of the Serbian government, the SL and the "structures" based on above mentioned factors has been publicly voiced by some Northern Serb politicians, irrespective of their stance on Kosovo institutions (Fazliu 2017; Milivojevic 2019). There have also been individual acts of resistance against the Serbian government's integration policy. ${ }^{18}$

Part of the old, weakened DSS-linked Northern Kosovo Serb leadership, like veteran politicians Marko Jakšić and Slaviša Ristić, regrouped in the hardline nationalist Otadžbina ("Fatherland") National Movement of Serbs from Kosovo and Metohija (Narodni pokret Srba sa Kosova i Metohije 'Otadžbina'). Founded in 2017, Otadžbina advocates the boycott of Kosovo institutions, including elections. Harshly critical of Vučić, it joined the Alliance for Serbia (Savez za Srbiju, SzS), Serbia's main opposition group in the 2018-2020 period, which rejected recognition of Kosovo's independence (Kossev 2019a; SzS N.d.). Otadžbina also joined SzS’s successor coalition, the United Opposition of Serbia (Udružena opozicija Srbije, UOS) (N1 2020). Otadžbina has urged Russia to take an assertive stance against Kosovo's independence as a counterweight to what the organization sees as the Serbian government's treasonous Kosovo policy under Vučić (Otadžbina 2018). ${ }^{19}$

Opposition in the North was also prominently represented by Oliver Ivanović. A former Bridge Watcher and state secretary at Serbia's ministry for Kosovo and Metohija (who later adopted more moderate stances, including competing in Kosovo system elections), Ivanović was the leader of the Civic Initiative Freedom, Democracy and Justice (Građanska inicijativa Sloboda, Demokratija, Pravda - GI SDP) and fierce critic of the political forces and trends in normalization-era North. His unresolved assassination in January 2018, commonly believed to be an intra-Serb politically motivated episode, became a symbol of political and security problems in normalization-era North (Milivojević 2019; Zupančič 2019, 582). ${ }^{20}$

18 For example, North Mitrovica mayoral elections in 2013-2014 were rerun because of the winner's refusal to take the oath of office with Kosovo state symbols (Bieber 2015, 310). Years later, some Serb judges refused to work in Kosovo's institutions (Mirović 2019, 186-191).

19 In what are often believed to be politically motivated episodes, Otadžbina's headquarters in North Mitrovica were destroyed in a fire in 2017, and Jakšić and Ristić had their property attacked since 2012 (Milivojevic 2019; Mirović 2019, 104; Zupančič 2019, 582).

20 Before his murder, Ivanović was harshly attacked in pro-government media in Serbia. Ivanović's family also suffered intimidation, and GI SDP's property was attacked. Four years before Ivanović's murder, his friend Dimitrije Janićijević, another Northern Kosovo Serb opposition politician, was assassinated in North Mitrovica (Milivojevic 2019). 
The Serbia-wide " 1 out of 5 million" anti-government demonstrations launched in 2018, which protested mainly against the deteriorated state of democracy in the country, but also against the SNS-led governments' policy on Kosovo, were also held in the North in 2019 with the participation of Otadžbina and other local political actors. Demonstrators also demanded the solving of the assassination of Oliver Ivanović (Kossev 2019d). Due to resource disparity, lack of external support, political divisions and the specificity of relations between the Northern Kosovo Serb community and Serbia, opposition activity did not grow so far to strongly impact the political status quo in the North. Nevertheless, it does point to latent challenges to the legitimacy and sustainability of normalization originating from dissatisfaction and insecurity with this process and associated trends.

\section{Conclusion}

North Kosovo emerged from the 1990s Kosovo war as the focus of a new dispute in the Balkans whose roots can be traced to the historical Serb-Albanian conflict within and over Kosovo. Defying the civilian and security authority framework under international auspices established in Kosovo in 1999, as well as Kosovo state authority and its Western backers after Kosovo's 2008 declaration of independence, the North's predominantly Serb population articulated with Belgrade to maintain a Serbia-supported selfrule system in the region. Highly integrated into Serbia's political system, it included judicial, educational, welfare, healthcare, public administration and security structures, leading to a de facto partition in Kosovo.

This began to change from 2011, when the normalization dialogue aimed at EU accession was launched. The Serbian government, under Western pressure and aware of economic dependence towards the EU, made key concessions in exchange for the advancement of its EU accession negotiations. Successive deals, particularly elements of the Brussels Agreement, to a great extent dismantled the Serbian Northern Kosovo system. They also led to a degree of extension of Kosovo's authority to the North and promoted local Serbs' participation in Kosovo's political system - goals long championed in Western conceptions of geopolitical stability in the Balkans.

This article analyzed political and security trends in the North during the normalization process, focusing on perspectives from the Northern Kosovo Serb community in the face of the interests and policies of the governments of Serbia, Kosovo and the US, as well as of the EU and its leading states. As the discussion indicated, normalization has had an authoritarian facet and generated discontent seen in several features of the region. Northern Kosovo Serbs and their old leadership overwhelm- 
ingly rejected Kosovo state authority, a fact that meant that the legitimacy of normalization and its outcomes were locally contested from their very beginning. Additionally, Northern Serbs, which were among the ones most impacted by the agreements, were not meaningfully included in the negotiations. Already at the time of the technical dialogue, dissatisfaction with aspects of normalization and the possibility of the extension of Priština's authority to the North translated into resistance mobilization by local actors, including in violent forms.

Although their sources sometimes were not new phenomena, signs of discontent, dissatisfaction and insecurity in the North kept widespread during normalization, as shown by diverse survey data. These perceptions often had to do both with formal aspects of normalization, like the Brussels Agreement and its consequences; and tacit/political ones, like the way the Serbian SNS-led governments and their local allies asserted their dominance over Northern Kosovo Serb politics. Lack of improvement of security and rule of law were also strongly perceived. Such negative assessments about the political, economic and security environment in the North belie normalization's promises of improvements in the region. Unsurprisingly, in this context, the prestige of the EU and the US - normalization's key international promoters - is significantly tarnished among Northern Serbs.

Political opposition mobilization, although so far not able to strongly impact the status quo in the region due to factors like relative lack of political and organizational strength, has appeared in connection with the several perceived political and security problems in normalization-era North. In view of these factors, it can be said that the experience of normalization-era North indicates that "stabilocratic" arrangements can meet some of the interests of their promoters at the central government and international levels. On the other hand, however, the way the normalization dialogue and associated processes developed led to sources of dissatisfaction and political counter-mobilization at a local level, thus pointing to latent challenges to the legitimacy and sustainability of normalization and its outcomes in North Kosovo.

\section{REFERENCES}

Al Jazeera. 2013. „Miting u sjevernom dijelu Mitrovice [Demonstration in the northern part of Mitrovica]", January 30, 2013; Available at http://balkans.aljazeera. net/vijesti/miting-u-sjevernom-dijelu-mitrovice, (Last accessed on 23.7.2020).

Alliance for Serbia [SzS]. N.d. „Program [Program]”; Available at https://savez-za-srbiju.rs/program/, (Last accessed on 23.7.2020).

Andrić Rakić, Milica. 2017. "Gvozdenom pesnicom za Srpsku listu [With an iron fist for the Serbian List]". Deutsche Welle, October 24, 2017; Available at https:// 
www.dw.com/sr/gvozdenom-pesnicom-za-srpsku-listu/a-41083481, (Last accessed on 23.7.2020).

2020. "Kurti pod baražnom paljbom zbog saradnje sa Srbima tokom pandemije [Kurti under barrage fire because of cooperation with Serbs during the pandemic]". Deutsche Welle, April 11, 2020; Available at https://www.dw.com/ sr/kurti-pod-bara\%C5\%BEnom-paljbom-zbog-saradnje-sa-srbima-tokom-pandemije/a-53093516, (Last accessed on 23.7.2020).

B92. 2019. "KFOR blames media and politicians; talks 'some tensions"', May 29, 2019; Available at https://www.b92.net/eng/news/politics.php?yyyy=2019\&m$\mathrm{m}=05 \& d d=29 \&$ nav_id=106922, (Last accessed on 23.7.2020).

Balkans Policy Research Group [BPRG]. 2017. “The Association of Serb Municipalities: understanding conflicting perspectives of Albanians and Serbs", January 22, 2017; Available at https://balkansgroup.org/wp-content/uploads/2017/o1/ BPRG_Pub-02_ASM_ENG_WEB.pdf, (Last accessed on 23.7.2020).

Bieber, Florian. 2015. "The Serbia-Kosovo Agreements: An EU Success Story?" Review of Central and East European Law, 40: 285-319. doi: 10.1163/1573035204003008 .

2018. "The Rise (and Fall) of Balkan Stabilitocracies". Horizons, 10 (Winter): $176-185$.

2020. The Rise of Authoritarianism in the Western Balkans. Cham: Palgrave Macmillan. doi: 10.1007/978-3-030-22149-2.

Bilbija, B.Đ. 2007. "Protest kosmetskih Srba pred američkom ambasadom [Protest of Serbs from Kosovo and Metohija in front of the American Embassy]". Politika, February 28, 2007; Available at http://www.politika.rs/sr/clanak/22659/ Protest-kosmetskih-Srba-pred-ameri\%C4\%8Dkom-ambasadom, (Last accessed on 23.7.2020).

Butcher, Jack. 2020. "New government formed with Avdullah Hoti as PM". Kosovo 2.o, June 3, 2020; Available at https://kosovotwopointzero.com/en/new-government-formed-with-avdullah-hoti-as-pm/, (Last accessed on 23.7.2020).

Capussela, Andrea Lorenzo. 2016. Izgradnja države na Kosovu. Demokratija, korupcija i EU na Balkanu [State-Building in Kosovo. Democracy, Corruption and the EU in the Balkans]. Belgrade: Službeni glasnik.

Clark, Janine Natalya. 2014. “Kosovo's Gordian knot: the contested north and the search for a solution". Nationalities Papers, 42(3): 526-547. doi: 10.1080/00905992.2013.870147.

Crno-beli svet [CBS]. 2018. „CBS istraživanje: Kriminal najveći problem za sever, sloboda kretanja za jug Kosova [CBS poll: crime is the biggest problem for the North, freedom of movement for the South of Kosovo]", September 4, 2018; Available at http://crnobelisvet.com/944-2/, (Last accessed on 23.7.2020).

Đorđević, Jelena. 2019. „Tabloidna logika - Platfoma o dijalogu isto što i rat sa 'Šiptarima' [Tabloid logic - Platform on dialogue same as a war with 'Shiptars']". 
Raskrinkavanje, March 8, 2019; Available at https://www.raskrikavanje.rs/ page.php?id=Tabloidna-logika---Platfoma-o-dijalogu-isto-sto-i-rat-sa-Siptarima-398, (Last accessed on 19.8.2020).

Đukanović, Dragan. 2013. „Odnosi između Beograda i Prištine: od tehničkog do političkog dijaloga [Relations between Belgrade and Priština: from technical to political dialogue]". Međunarodna politika, 65(3):365-385. doi: 10.2298/MEDJP1303365D.

Dragojlov, Aleksandra. 2020. "Multi-level Games: The Serbian Government’s Strategy towards Kosovo and the EU under the Progressive Party". Southeast European and Black Sea Studies. doi: 10.1080/14683857.2020.1778985.

Economides, Spyros and Ker-Lindsay, James. 2015. “'Pre-Accession Europeanization': The Case of Serbia and Kosovo". Journal of Common Market Studies, 53(5): 1027-1044. doi: 10.1111/jcms.12238.

Emini, Donika and Stakić, Isidora. 2018. "Belgrade and Pristina: lost in normalisation?" European Union Institute for Security Studies (EUISS); Available at https://www.iss.europa.eu/sites/default/files/EUISSFiles/Brief\%205\%2oBelgrade\%2oand\%2oPristina.pdf, (Last accessed on 23.7.2020).

European Western Balkans [EWB]. 2020a. "Serb MPs voted only for their own ministers in the Kosovo government, media report", February 4, 2020; Available at https://europeanwesternbalkans.com/2020/o2/o4/serb-mps-voted-onlyfor-their-own-ministers-in-the-kosovo-government-media-report/, (Last accessed on 23.7.2020).

202ob. "The Office of the PM of Kosovo: Thaçi signed a secret agreement and violated the Constitution; dismissal required", February 26, 2020; Available at https://europeanwesternbalkans.com/2020/o2/26/the-office-of-the-pmof-kosovo-thaci-signed-a-secret-agreement-and-violated-the-constitution-dismissal-required/, (Last accessed on 23.7.2020).

Fazliu, Eraldin. 2017. "What choice for Kosovo's Serbs ?" Kosovo 2.o, October 20, 2017; Available at https://kosovotwopointzero.com/en/choice-kosovos-serbs/, (Last accessed on 23.7.2020).

Gus'kova, Elena. 2013. Agressiia NATO 1999 goda protiv Iugoslavii i protsess mirnogo uregulirovaniia [The 1999 NATO aggression against Yugoslavia and the peace process]. Moscow: Indrik.

Headley, James. 2008. Russia and the Balkans: Foreign Policy from Yeltsin to Putin. London: Hurst Publishers.

Helsinški odbor za ljudska prava u Srbiji [Helsinki Committee for Human Rights in Serbia, HCHRS]. 2019. Srpska zajednica na Kosovu: Zamrznut život u zamrznutom konfliktu [The Serb community in Kosovo: frozen life in a frozen conflict].

Insajder. 2012. „Patriotska pljačka. Transkript šeste epizode [The Patriotic Looting. Transcript of the sixth episode]", November 14, 2012; Available at https://insajder.net/sr/sajt/patriotska/222/Transkript-\%C5\%Areste-epizode.htm, (Last accessed on 23.7.2020). 
International Crisis Group [ICG]. 2001. “Kosovo: landmark election”, November 21, 2001; Available at https://d2071andvipowj.cloudfront.net/120-kosovo-landmark-election.pdf, (Last accessed on 23.7.2020).

2002. "UNMIK’s Kosovo Albatross: Tackling Division in Mitrovica”, June 3, 2002; Available at https://d2071andvipowj.cloudfront.net/131-unmik-s-kosovo-albatross-tackling-division-in-mitrovica.pdf, (Last accessed on 23.7.2020).

2004. "Collapse in Kosovo", April 22, 2004; Available at https://d2071andvipowj.cloudfront.net/155-collapse-in-kosovo.pdf, (Last accessed on 23.7.2020).

2005. "Bridging Kosovo's Mitrovica divide", September 13, 2005; Available at https://d2071andvipowj.cloudfront.net/Bridging\%2oKosovo's\%2oMitrovica\%20Divide.pdf, (Last accessed on 23.7.2020).

2008. “Kosovo's Fragile Transition”, September 25, 2008; Available at https:// d2071andvipowj.cloudfront.net/196-kosovo-s-fragile-transition.pdf, (Last accessed on 23.7.2020).

2009. "Serb integration in Kosovo: taking the plunge", May 12, 2009; Available at https://d2071andvipowj.cloudfront.net/20o-serb-integration-in-kosovo-taking-the-plunge.pdf, (Last accessed on 23.7.2020).

2011. "North Kosovo: dual sovereignty in practice", March 14, 2011; Available at https://d2071andvipowj.cloudfront.net/211-north-kosovo-dual-sovereignty-in-practice.pdf, (Last accessed on 23.7.2020).

2012. "Kosovo and Serbia: a little goodwill could go a long way", February 2, 2012; Available at https://d2071andvipowj.cloudfront.net/215-kosovo-andserbia-a-little-goodwill-could-go-a-long-way.pdf, (Last accessed on 23.7.2020).

2013. "Serbia and Kosovo: the Path to Normalisation", February 19, 2013; Available at https://d2071andvipowj.cloudfront.net/serbia-and-kosovo-the-path-to-normalisation.pdf, (Last accessed on 23.7.2020).

Jović, Dejan. 2009. Yugoslavia: a state that withered away. West Lafayette: Purdue University Press.

Jović, Nikola; Andrić, Milica and Marinković, Miodrag. 2017. "Trend Analysis: Citizens Opinion Survey in North Kosovo”. Aktiv. Available at http://www.ngoaktiv. org/uploads/files/Trend\%2oAnalysis\%202017.pdf, (Last accessed on 23.7.2020).

Jović, Nikola, Andrić, Milica and Ostojić, Sara. 2016. “Trend Analysis: Citizens' attitudes in north Kosovo". Aktiv. Available at http://www.ngoaktiv.org/uploads/ files/trend\%2oanalysis\%2odraft\%2o(1).pdf, (Last accessed on 23.7.2020).

Jović, Nikola and Nešović, Branislav. 2015. "Views of the citizens in north Kosovo. Political, economic and security aspects". Aktiv and Center for Peace and Tolerance. Available at http://www.ngoaktiv.org/uploads/files/Views\%20of\%20 the\%2ocitizens\%2oin\%2onorth\%20Kosovo.pdf, (Last accessed on 23.7.2020).

Jović, Nikola, Waugh, Caleb and Marinković, Miodrag. 2018. "Citizens' attitudes in the north of Kosovo". Aktiv; Available at http://www.ngoaktiv.org/uploads/ files/Trend\%2oAnalysis\%202018\%2o(eng).pdf, (Last accessed on 23.7.2020). 
Ker-Lindsay, James. 2009. Kosovo. The Path to Contested Statehood in the Balkans. London and New York: I. B. Tauris.

Kolesnikov, Andrei. 2018. "S legkim serbtsem [With a light Serb]". Kommersant, October 3 2018; Available at https://www.kommersant.ru/doc/3758959, (Last accessed on 23.7.2020).

Kosovo Central Election Commission [KCEC]. 2019a. „Izbori za Skupštinu Kosova 2019. Konačni rezultati. Rezultati po opštinama [Kosovo Assembly Election 2019. Final Results. Results by municipalities]"; Available at http://www.kqzks.org/wp-content/uploads/2019/11/7.Rezultatet-e-subjekteve-sipas-komunave.pdf, (Last accessed on 23·7.2020).

2019b. „Vanredni izbori za predsednika opštine 2019 - konačni rezultati za opštinu [Extraordinary mayoral elections in 2019 - final results by municipality]"; Available at http://www.kqz-ks.org/wp-content/uploads/2019/o5/1.-Rezultatet-sipas-komunave-2.pdf, (Last accessed on 23.7.2020).

Kossev. 2019a. “Kosovo Serb political landscape: Otadzbina”, September 3, 2019; Available at https://kossev.info/kosovo-serb-political-landscape-otadzbina/, (Last accessed on 23.7.2020).

2019b. "Kosovo Serb political landscape: Srpska lista”, October 3, 2019; Available at https://kossev.info/kosovo-serb-political-landscape-srpska-lista/, (Last accessed on 23.7.2020).

2019c. "Narodna skupština o nacrtu budžeta za 2020: Za Kosovo planirano skoro 11 milijardi dinara [The National Assembly on the draft budget for 2020: nearly 11 billion Dinars planned for Kosovo]", November 20, 2019; Available at https://kossev.info/narodna-skupstina-o-nacrtu-buzeta-za-2020-za-kosovo-planirano-skoro-11-milijardi-dinara/, (Last accessed on 23.7.2020).

. 2019d. "The third '1 out of 5 million' protest held in North Mitrovica yesterday", March 8, 2019; Available at https://kossev.info/the-third-1-out-of-5-million-protest-held-in-north-mitrovica-yesterday/, (Last accessed on 23-7.2020).

2020. "Kadrovske promene u Privremenim organima opština sa KiM [Personnel changes in the Provisional Authorities of Municipalities of Kosovo and Metohija]", March 5, 2020; Available at https://kossev.info/vlada-srbije-imenovani-i-razreseni-clanovi-i-predsednici-privremenih-organa-opstina-sa-kim/, (Last accessed on 23.7.2020).

Lončar, Jelena. 2019. "Voices of the Serb minority in the Assembly of Kosovo". In ed. Gëzim Visoka and Vjosa Musliu. Unravelling Liberal Interventionism: Local Critiques of Statebuilding in Kosovo. New York: Routledge. doi: 10.4324/9780429507649-8.

Loxha, Amra Zejneli. 2019. "Srpski rukovodioci sa kosovskim platama [Serbian directors with Kosovo wages].” Radio Slobodna Evropa, February 26, 2019; Available at https://www.slobodnaevropa.org/a/kosovo-paralelne-strukture-lokalna-samouprava-srbija/29792112.html, (Last accessed on 23.7.2020). 
Marinković, Miodrag Miki; Timotijević, Miloš and Kostić, Senka. 2019. “Trend Analysis 2019. Attitudes of the Serbian Community in Kosovo". Aktiv. Available at http://ngoaktiv.org/uploads/files/Trend\%20Analysis\%202019.pdf, (Last accessed on 23.7.2020).

Milivojevic, Andjela. 2019. "Bombs and Bullets: Fear and Loathing in North Kosovo”. Balkan Insight, January 16, 2019; Available at https://balkaninsight.com/2019/o1/16/bombs-and-bullets-fear-and-loathing-in-north-kosovo-01-14-20191/, (Last accessed on 23-7.2020).

Mirović, Dejan. 2019. Briselski sporazum: hronologija i posledice [The Brussels Agreement: chronology and consequences]. Belgrade: Catena Mundi.

N1. 2020. Formirana Udružena opozicija, cilj - smena režima i izgradnja slobodnog društva [United Opposition formed, goal - regime change and the construction of a free society], August 10, 2020; Available at http://rs.ninfo.com/ Vesti/a628268/Formirana-Udruzena-opozicija-Srbije.html, (Last accessed on 19.8.2020).

Nogueira, Arthur H.V. 2015. Kôssovo: província ou país ? [Kosovo: province or country ?]. Brasília: FUNAG.

OSCE. 2003. "Parallel Structures in Kosovo"; Available at https://www.osce.org/ files/f/documents/9/1/42584.pdf, (Last accessed on 23.7.2020).

2007. "Parallel Structures in Kosovo 2006-2007"; Available at https://www. osce.org/files/f/documents/f/f/24618.pdf, (Last accessed on 23.7.2020).

2019. "Municipal Profiles 2018"; Available at https://www.osce.org/files/ Municipal\%20Profiles_2018.pdf, (Last accessed on 23.7.2020).

Otadžbina. 2018. „Otvoreno pismo Vladimiru Putinu [Open letter to Vladimir Putin]", June 28, 2018; Available at http://www.nspm.rs/hronika/otadzbina-otvoreno-pismo-vladimiru-putinu-prijateljstvom-rusije-i-susretima-sa-vama-rezim-aleksandra-vucica-pred-domacom-javnoscu-prikriva-svoju-kosovsku-izdaju.html, (Last accessed on 23-7.2020).

Pavlović, Dušan. 2020. "The political economy behind the gradual demise of democratic institutions in Serbia”. Southeast European and Black Sea Studies, 20(1): 19-39. doi: 10.1080/14683857.2019.1672929.

Pavlović, Srđa. 2017. "West is best: How 'stabilitocracy' undermines democracy building in the Balkans." EUROPP, May 5, 2017; Available at https://blogs.lse. ac.uk/europpblog/2017/o5/o5/west-is-best-how-stabilitocracy-undermines-democracy-building-in-the-balkans/, (Last accessed on 23.7.2020).

Politika. 2011. „Iz Rusije stiglo 35 tona pomoći za Srbe na Kosovu [35 tons of aid for Serbs in Kosovo arrived from Russia]", November 17, 2011; Available at http:// www.politika.rs/sr/clanak/198127/Iz-Rusije-stiglo-35-tona-pomoci-za-Srbe-naKosovu, (Last accessed on 23.7.2020).

Prelec, Marko and Rashiti, Naim. 2015. "Serb Integration in Kosovo After the Brussels Agreement”. Balkans Policy Research Group, March 19, 2015; Avail- 
GUSTAVO OLIVEIRA TELES DE MENEZES

NORTH KOSOVO AND THE SERBIA-KOSOVO NORMALIZATION DIALOGUE

able at https://balkansgroup.org/wp-content/uploads/2015/o3/Serb-Integration-in-Kosovo-After-Brussels-Agreement.pdf, (Last accessed on 23.7.2020).

Radio Free Europe [RFE]. 2019. "Final Vote Results Confirm Self-Determination's Victory In Kosovo”, November 7, 2019; Available at https://www.rferl.org/a/final-vote-results-confirm-vetevendosje-victory-in-kosovo/30258247.html, (Last accessed on 23.7.2020).

Ristanović, Petar. 2019. Kosovsko pitanje: 1974-1989 [The Kosovo Question: 19741989]. Novi Sad: Prometej.

Roriz, João H. R. 2015. "Administrando a imparcialidade: a ONU e a independência de Kosovo [Managing Impartiality: the UN and Kosovo Independence]". Carta Internacional, 10(2): 146-162. doi: 10.21530/ci.v1on2.2015.286.

RTS. 2012. „Sever Kosova neće Prištinu [North Kosovo does not want Priština]”, February 15, 2012; Available at https://www.rts.rs/page/stories/sr/story/9/politika/1045398/sever-kosova-nece-pristinu.html, (Last accessed on 23.7.2020).

2019. „Vučić pozvao da se glasa za Srpsku listu [Vučić called for votes for the Serbian List]", October 1, 2019; Available at http://www.rts.rs/page/stories/ci/ story/1/politika/3679751/vucic-pozvao-da-se-glasa-za-srpsku-listu.html, (Last accessed on 23.7.2020).

Samedova, Evlaliia. 2012. „Moskva solidarna s kosovskimi serbami, no grazhdanstvo im ne dala [Moscow in solidarity with Kosovo Serbs, but did not grant them citizenship]". Deutsche Welle, February 14, 2012; Available at https://www.dw.com/ $\mathrm{ru} /$ москва-солидарна-с-косовскими-сербами-но-гражданство-им-не-дала/а-15741216, (Last accessed on 23.7.2020).

Serbia. 2013a. "First Agreement of Principles Governing the Normalization of Relations"; Available at https://www.srbija.gov.rs/cinjenice/en/120394, (Last accessed on 24.7.2020).

2013b. „Politička platforma za razgovore sa predstavnicima Privremenih institucija samouprave na Kosovu i Metohiji [Political platform for talks with representatives of the Provisional Institutions of Self-government in Kosovo and Metohija]"; Available at https://www.predsednik.rs/pres-centar/vesti/politicka-platforma-za-razgovore-sa-predstavnicima-privremenih-institucija, (Last accessed on 23.7.2020).

2013c. „Rezolucija Narodne skupštine Republike Srbije o osnovnim principima za političke razgovore sa privremenim institucijama samouprave na Kosovu i Metohiji [Resolution of the National Assembly of the Republic of Serbia on the basic principles for political talks with the Provisional Institutions of Self-government in Kosovo and Metohija]", January 13, 2013; Available at https://media.srbija.gov.rs/medsrp/dokumenti/rezolucija-kimı3o113_cyr.pdf, (Last accessed on 23.7.2020).

2015. "Association/Community of Serb majority municipalities in Kosovo - general principles/main elements"; Available at http://www.kord-kim.gov.rs/ eng/p17.php, (Last accessed on 24.7.2020). 


\section{6 \\ POLITIČKE PERSPEKTIVE \\ OSVRTI, PRIKAZI, RECENZIJE}

. 2018. „Izveštaj o napretku u dijalogu Beograda i Prištine (za period od 1. maja 2018. do 15. decembra 2018. godine) [Report on the progress of the Belgrade-Priština dialogue (for the period from 1 May 2018 to 15 December 2018)]"; Available at http://www.kim.gov.rs/doc/pregovaracki-proces/Sestomesecni\%2oizvestaj\%200\%2odijalogu\%2odec\%202018.pdf, (Last accessed on 23.7.2020).

. 2019a. „Đurić: Srpska lista državni projekat koji predstavlja jedinstvo sa Beogradom [Đurić: the Serbian List is a state project that represents unity with Belgrade]", October 6, 2019; Available at http://www.kim.gov.rs/lat/v3426.php, (Last accessed on 23.7.2020).

2019b. „Izveštaj o Kosovu i Metohiji [Report on Kosovo and Metohija]”; Available at http://www.parlament.gov.rs/upload/archive/files/cir/pdf/akta_ procedura/2019/02-1719_19_Izvestaj.pdf, (Last accessed on 23.7.2020).

. 2020. „Ukupni rezultati izbora za narodne poslanike Narodne skupštine 2020. godine. Rezultati po opštinama [Overall results of the 2020 election for MPs of the National Assembly. Results by municipality]"; Available at https://www. rik.parlament.gov.rs/tekst/sr/9386/ukupni-rezultati-izbora-za-narodne-poslanike-narodne-skupstine-2020-godine.php, (Last accessed on 23.7.2020).

Serbian List [SL]. N.d. „O nama [About us]”; Available at http://srpskalista.net/onama/, (Last accessed on 23.7.2020).

2019. „Saopštenje Srpske liste” [Statement by the Serbian List]”, October 11, 2019; Available at https://www.facebook.com/srpskalista.net/posts/2402265543426542, (Last accessed on 23.7.2020).

Serbian Progressive Party [SNS]. 2011. „Bela knjiga 'programom do promena' [The White Book 'through program to changes']", October 2011; Available at https://www.sns.org.rs/sites/default/files/bela-knjiga_o.pdf, (Last accessed on 23.7.2020).

Solov'ev, Vladimir. 2011. "Chem serbstvo uspokoitsia [With what Serbhood will calm down]”. Kommersant, November 28, 2011; Available at https://www.kommersant.ru/doc/1825838, (Last accessed on 23.7.2020).

Socialist Party of Serbia [SPS]. 2010. „Program Socijalističke partije Srbije [Program of the Socialist Party of Serbia]", December 11, 2010; Available at https://www. sps.org.rs/documents/PROGRAM\%2oSPS.pdf, (Last accessed on 23.7.2020).

Stakić, Isidora and Bjeloš, Maja. 2015. "The future of Civil Protection in North Kosovo". Belgrade and Prishtina: Belgrade Centre for Security Policy and Kosovar Center for Security Studies; Available at http://www.bezbednost.org/upload/ document/the_future_of_civil_protection_in_north_kosovo.pdf, (Last accessed on 23.7.2020).

Surk, Barbara. 2019. "Push for Deal Between Kosovo and Serbia Puts National Divisions on Display." The New York Times, April 29, 2019; Available at https:// www.nytimes.com/2019/o4/29/world/europe/kosovo-serbia.html, (Last accessed on $23 \cdot 7 \cdot 2020$ ). 
Trapara, Vladimir. 2016. „Finlandizacija postpetooktobarske Srbije [The Finlandization of Post-5 October Serbia]”. In Ed. Srđan T. Korać. Uticaj vojne neutralnosti Srbije na bezbednost i stabilnost u Evropi [The influence of Serbia's military neutrality on security and stability in Europe]. Belgrade: Institut za međunarodnu politiku i privredu and Hans Seidell Stiftung.

Traynor, Ian. 2010. "WikiLeaks cables: Kosovo sliding towards partition, Washington told." The Guardian, December 9, 2010; Available at https://www.theguardian.com/world/2010/dec/o9/wikileaks-cables-kosovo-independence-serbia, (Last accessed on 23.7.2020).

Trivić, Branka and Loxha, Amra Zejneli. 2019. „Svedočenje sa Kosova: ’Morali da glasaju jer rade u srpskoj instituciji' [Testimony from Kosovo: 'They had to vote because they work in a Serbian institution']." Radio Slobodna Evropa, October 9, 2019; Available at https://www.slobodnaevropa.org/a/srbi-na-kosovu-izbori/30207929.html, (Last accessed on 23.7.2020).

Tuhina, Gjeraqina. 2019. „Tači 2013. obećao NATO-u da KBS neće na sever Kosova bez saglasnosti KFOR-a [In 2013, Thaçi promised NATO that the KSF will not enter North Kosovo without KFOR's consent]". Radio Slobodna Evropa, February 13, 2019; Available at https://www.slobodnaevropa.org/a/29768536.html, (Last accessed on 23.7.2020).

United Nations [UN]. 1999. "United Nations Security Council Resolution 1244", June 10, 1999; Available at https://digitallibrary.un.org/record/274488, (Last accessed on 23.7.2020).

2010. "United Nations General Assembly Resolution A/RES/64/298”, September 9, 2010; Available at https://www.securitycouncilreport.org/atf/cf/\%7B65BFCF9B-6D27-4E9C-8CD3-CF6E4FF96FF9\%7D/ROL\%2oA\%2oRES64\%20 298.pdf, (Last accessed on 23.7.2020).

Vladisavljević, Nebojša. 2012. "Kosovo and Two Dimensions of the Contemporary Serb-Albanian Conflict”. In Ed. Robert Hudson and Glenn Bowman. After Yugoslavia. Identities and Politics within the Successor States. New York: Palgrave Macmillan.

2019. Uspon i pad demokratije posle Petog oktobra [The rise and fall of democracy after 5 October]. Belgrade: Arhipelag.

Xharra, Jeta. 2020. "More land swap lobbying uncovered”. Prishtina Insight, June 9, 2020; Available at https://prishtinainsight.com/more-land-swap-lobbying-uncovered/, (Last accessed on 23.7.2020).

Zupančič, Rok. 2019. "EU peace-building in the north of Kosovo and psychosocial implications for the locals: a bottom up perspective on normative power Europe". Journal of Balkan and Near Eastern Studies, 21(5): 576-593. doi: 10.1080/19448953.2018.1504379. 
